\title{
SOCIAL EXCLUSION OF SENIORS AS PSYCHOLOGICAL PROBLEM: THEORETICAL ASPECT
}

Olesya Koropetska (Ivano-Frankivsk)

\author{
Vasyl Stefanyk Precarpathian National University, Ivano-Frankivsk, Ukraine \\ - Ph.D., Associate Professor, Department of Social and Development Psychology
}

Background: According to the last demographers' and psychologists' investigations ageing of societies has become an increasingly mass and progressing phenomenon. According to statistics, the average lifespan of people at the beginning of the twentieth century was 47-55 years and today it is around 85, the difference is about 30 years (Stuart Hamilton, Psychology of Ageing, 2010, p.15). As the result, the growth rate of the number of the elderly in the world is twice the population growth as a whole. At the same time in many countries the seniors usually are perceived as useless for the system and helpless in the face of changes. In this reason very often they find themselves out of society, they feel excluded from society and a number of problems have appeared just with that phenomenon. The most important of them are: the problems of social adaptation and social exclusion of seniors, the problems of effective using of professional potential of the elderly and creating conditions for their further education, the problem of their productive life and self-realization in this period of ontogeny. These problems require more deep investigation of the phenomenon of social exclusion, its conceptualization as newish research frame, justifying the psychological essence of the concept, investigations in the field of late adulthood, physical and psychological possibilities people in the period of senescence.

Purpose: The study aim is tojustify a scientific meaning of the concept, to analyze the essence of the elderly period of ontogeny and to consider the factors that contribute to the social exclusion of elderly people in order to be recognized and resolved in time.

Methods: Theoretical methods (analysis, synthesis, comparison, generalization) were used to justify scientific meaning of the concept, to analyze the essence of the elderly period of ontogeny and to consider the factors that contribute to the social exclusion of elderly people.

Results: The term "social exclusion" appeared at the end of the twentieth century. French governor Rene Lenoir (René Lenoir) introduced this term during the study of such social phenomena as poverty, marginalization, deprivation and others (Lenoir R., 1989). In particular R.Lenoir stated that $10 \%$ of French society in the 1980-ies was socially excluded: people with mental or physical disorders, bent on self-destruction, disabled, children subjected to violence, drug users, criminals and other social misfits. According to these indicatorssocial exclusion is a complex phenomenon where not only formal parameters, but such psychological factors as self- 
identification, psychological state and way of life of a person should be taken into account. The new concept has a number of different meanings. The most common understanding of social exclusion is that a person, lacking the resources or being denied rights, can't buy goods and use social services. She is deprived the ability to participate in the normal social relationships and social activities, which are available to the majority of people in society. The result of such lack has a negative effect on both as the quality of life of a person and on the quality of life of the whole families or communities (P.Townsend). It is used to describe the limitation or deprivation of rights in civil law, such as restricting access to institutions of social integration (Geddes and Benington, 2001).

An important contribution to understanding of this concept madeP. Abrahamson, R.Atkinson, F.Borodkin,T.Baraulyna,K.Duffy, H.Dean, J.Friedman, Ch.Gore, B.Jordan, A.de Haan, J.Hobearft, D. Hom'en, S J. Houf, S.Maxwell, G.Rodgers, S.Pauham, A.Power, J.PercySmith, A.Sen, V.R.Schmidt, P.Townsend, W.Wilson, M.Wolf, L.Zvaak and others. In general, "social exclusion' means the separation of individuals and groups from mainstream of society (Commins 2004; Moffatt and Glasgow 2009). The opposite to social exclusion is the concept of social inclusion, which means having good relationships with family and friends, having a social role, feeling useful in society and useful to others, and to be treated by others with respect. Combating social exclusion for all groups, including the elderly, has been a major aim of all successful governments.

There are several theories of social exclusion that interpret the state, feelings, inner world of excluded individual: «the theory of separation», "theory of liberation" (alienation) and "the theory of activeness" (E.Cumming, W.Henry B.Nyuharten,J. Rosen, H.Silver, P. Townsend). Social exclusion for seniors means the limitations, connected with ageing or with forced retirement, when a person loses not only a job, but the level of well-being, the social status, social ties (G. Rum).

Obviously, the man who identifies himself to mainstream must have means of subsistence, permanent work, income, property, land, housing, certain consumption, education, cultural capital, citizenship and respect (Silver H.).

The period of old age is the final stage of human life and it is important, that during this period all can feel, that their life still has a sense, which helps everybody to live actively and productively (L.Antsyferova, O.Krasnova, E. Erikson, ets.).

Psychological age is relative and the criteria of age periodization and life expectancy depends on the biological characteristics of the organism and on the social environmental factors. No doubt, that biological life expectancy is determined by its genetic constitution, but it is usually not fully realized due to deleterious effects of social conditions. At the same time, biological life serves as a guide for the real sequel average life expectancy. The difference between these two values is the reserve, which can be realized by improving the conditions and life styles. However, 
still nowadays psychologists, gerontologists and physicians can't determine when the elderly period begins. Most of all (B. Przhyhoda, E.B. Harlok, J. Birren, D. B. Bromley etc.) consider, that it is 60-65 years, but the others believe, that no one of calendar dates are unacceptable (I. B. Davydovskiy), because aging is enormously an individual process. The most important psychological factor of aging is the acceptance by a person her age (N.F. Shakhmatov).

But despite the difficulties of modern life, people can't get rid of their social nature, which manifests itself in the need to realize one's own "I" in the activities of the society and to be evaluated by the society. The conflict between personal desire for activity and social aspects of exclusion updates the topics of self-realization in old age and encourages a person to find the relevant system solutions for restoration of social activity, social capital and connections, which are basic condition for self-realization. The peculiarity of social exclusion in old period of ontogeny is ageism - the deprivation by age criterion, which can affect anyone in the lderly period of life. The great experience and ability to examine the life and events in it in different coordinate systems allow the elderly people to find a new occupation, try to realize themselves in a new work, take part in a new social or any other kinds of activity and build a productive life after retirement (L.Antsyferova ).

High cognitive formations and positive acquisition, that are inherent to people in late adulthood, such as dialectical thinking (K. Rigel), wisdom (E. Erickson, P. Baltes) indicate to a high level of integration and integrity of the individuals and ability to fulfill complex kinds of work with different level of intellectual tasks and give useful advices on vital issues. But society treats the elderly as the objects of influence, which require care and maintenance. It does not want to see the seniors as socially active business partners that seek to meet their life important needs through collaboration with various social institutions and organizations, to develop their skills and take responsibility for their actions and decisions.

This tradition of attitude towards senior people is supported by society, which doesn't take care about those, who trapped in poverty, survives with low income and limits themselves in satisfaction of the elementary human needs. That is why, retirees often seek additional sources of income, settle for a job, that does not fit their profession. These facts indicate that the social activity of seniors is not implemented with the support of society, but it is rather their attempt to survive. Conclusion:Social exclusion, as the bilateral process, should be considered in two aspects: personal and social. The returning of elderly people to the mainstream depends on social and personal factors. The responsibility for a successful return of the excluded people to the social stream lies both on society and the individual.

The development of personality in old age period has its specificity, which is connected with influence of age and retirement. Human development in later years is more influenced not by 
biological aging, but by socio-psychological factors, such as ageism and a great number of social stereotypes. The solution of the above problemsrequires a more thorough study of this period of ontogeny, forming a new attitude towards the elderly and their participation in social development, the creation of programs of psychological support of "positive ageing and the search for a new forms of cooperation, involving the elderly to active social life.

Keywords: social exclusion, seniors, late adulthood, self-realization, social inclusion, personal and social development

\section{References}

Abrahamson, P. (2001) Combating poverty and social exclusion, in: Social sciences and modernity, №2. (p.148-166).

American Academy of Political and Social Science.- Vol. 415. (p. 187-198).

Antcyferova, L.Y. (2006). Development of personality and gerontology' problems. - M. -512 s.

Atkinson, A. B. (1998). "Social Exclusion, Poverty and Unemployment" in A. B. Atkinson and J. Hills Exclusion, Employment and Opportunity, CASE Paper 4,London: Centre for Analysis of Social Exclusion, London School of Economics

Krasnova, O.V. (1997). Socio-psychological questions of senescence Tekst. Practical psychology Jornal. №3. (p.3-19).

Hamilton, S. (2010). Psychology of Ageing. - SPb.: Pyter, - 320 p . (p.15).

Lenoir, R. (1989). Les Exclus: Un Francais sur Dix 2nd ed. - Paris: Editions du Seuil

Maksymenko, S. D. (2006). Gheneza zdijsnennja osobystosti - K.: Vydavnyctvo TOV «KMM», -240 p.

Neugarten, B. L. (1974). Age groups in American society and the rise of young-old. Annals of the Silver, H. (1994). "Social Exclusion and Social Solidarity: Three Paradigms" in International Labour Review,133 (5-6) p. 531 -578.

Silver, H. (1995) Reconceptualizing Social Disadvantge: Three Paradigmsof Social Exclusion. In Social Exclusion: Rhetoric, Reality, Responses, edited by Gerry Rodgers, Charles Gore, and Jose Figueiredo. - Geneva: International Institute forLabour Studies,.

Townsend, P. (1993) The international analysis of poverty. New York: Harvester Wheatsceaf. 